\title{
Combining theory and wisdom in pragmatic, scenario-based decision support for sustainable development
}

Megan Leigh Davenport ${ }^{\mathrm{a} *}$, Marion Delport ${ }^{\mathrm{a}}$, James Nelson Blignaut ${ }^{\mathrm{b}}$, Tanja Hichert $^{\mathrm{c}}$, Gerhard van der Burgh ${ }^{\mathrm{a}}$

Author affiliations: ${ }^{a}$ Bureau for Food and Agricultural Policy (BFAP), Department of Agricultural Economics, University of Pretoria, Pretoria, South Africa; ${ }^{b}$ Department of Economics, University of Pretoria, Pretoria, South Africa; Saeon (www.saeon.ac.co.za), South Africa; ${ }^{\mathrm{c}}$ Hichert \& Associates (Pty) Ltd, Somerset West, South Africa

\section{Correspondence details:}

Email: meganblore@gmail.com

Full postal details: University of Pretoria, Private bag X20, Hatfield 0028, South Africa Tel: +16143028082

Fax: +27 124204958

\section{Acknowledgements}

The authors would like to gratefully acknowledge the South African Maize Trust for providing financial support to this research project, as well as the workshop panellists for their participation and insight. This study also benefited greatly from the valuable comments and suggestions provided by R.M. Hassan. The views expressed and all errors in this paper remain the sole responsibility of the authors. 


\begin{abstract}
Researchers have increasingly acknowledged the relative strength of 'hybrid' approaches to scenario analysis for exploring the futures of coupled human-nature systems. In this paper, we explain, demonstrate, and provisionally evaluate the usefulness of a simple analytical framework, based on five categories of capital assets, as part of a protocol for overcoming the conversion problem in hybrid scenario analysis. Based on a preliminary application of the framework to a case study in South Africa, we suggest that the five capitals framework has the potential to improve the expedience and counter the bias against 'soft' drivers in hybrid approaches to scenario analysis. However, in light of the methodological trade-off between rigour and expedience, we suggest that future research needs to compare the available protocols for hybrid scenario analysis by weighing up the relative gain in scenario quality versus the relative cost of scenario construction.
\end{abstract}

Keywords: scenario analysis; sustainable development; decision support; five capitals; storyand-simulation

\title{
1. Introduction
}

The world faces a multitude of urgent, complex and interrelated environmental, social, and economic problems (Biggs et al. 2011; Millenium Ecosystem Assessment 2005; Rockström et al. 2009). As a result, there have been persistent calls for sustainable development as a means of dealing with these problems, the most recent of which is reflected in the United Nation's 2030 Agenda for sustainable development and its accompanying Sustainable Development Goals (United Nations 2016).

However, the inherently normative dimension of sustainable development (Robinson 2004) and the complexity of coupled social-ecological systems (Folke et al. 2002) give rise to a number of challenges which impede the path to a sustainable future. For instance, in the domain of sustainability science, researchers face several institutional, epistemological and methodological challenges related to transdisciplinary, problem-driven, multiscale and long- 
term research (Bai et al. 2015; Esler et al. 2016; Kates et al. 2001). Outside of academia, public managers and policy makers face the perplexing task of encouraging public participation and establishing adaptive and/or cooperative governance systems (Biggs et al. 2015), oftentimes with constrained decision-making horizons, considerable uncertainty, and limited expertise and budgets (e.g. Blore, Cundill, and Mkhulisi 2013).

Scenario analysis has emerged as one of several methodologies which researchers and policy makers have found useful in overcoming some of the academic and practical challenges associated with sustainable development (Bai et al. 2015; Folke et al. 2002; Swart, Raskin, and Robinson 2004). In particular, researchers have increasingly acknowledged the relative strength of 'hybrid' approaches to scenario analysis (broadly referring to approaches that combine qualitative and quantitative scenario methodologies) for exploring the futures of coupled human-nature systems (Kemp-Benedict 2004; Kosow 2011). Nonetheless, hybrid approaches are hampered by a number of weaknesses, chief among which is the difficulty of transforming narrative statements embedded in scenario storylines into quantifiable parameters for numerical modelling (Alcamo 2008) (for convenience, we refer to this issue as the 'conversion problem'). Furthermore, innovative methods devised to address the problem of converting "narrative to number" (sensu Kemp-Benedict 2004) tend to downplay the importance of 'soft' (i.e. intangible, difficult-to-quantify) drivers (cf. Booth et al. 2016) and have demanding requirements which are impractical for decision-makers and government agencies facing time, financial, and human-resource constraints.

The objective of this paper is to explain, demonstrate, and provisionally evaluate the usefulness of a simple analytical framework - built around five categories of capital assets- which has the potential to improve the expedience and counter the bias against 'soft' drivers in hybrid approaches to scenario analysis. By presenting the five capitals framework, our intention is to offer a tool which enhances the feasibility of hybrid scenario analysis for resource-constrained government agencies, researchers and decision-makers working in the crucial, but challenging, domain of sustainable development. The remainder of this paper is structured as follows: In Section 2, we first provide a background to the use of scenario analysis in the context of sustainable development, then we build a rationale for the five capitals analytical framework by highlighting the strengths and weaknesses of hybrid approaches to scenario analysis. Thereafter, the rest of the paper is dedicated to the explanation and theoretical justification 
(Section 3), demonstration (Section 4) and evaluation (Section 5) of the five capitals analytical framework as it applies to hybrid scenario methodologies. We conclude in Section 6.

\section{Scenario analysis and sustainable development}

Alcamo $(2008,16)$ describes scenario analysis as "a procedure covering the development of scenarios, comparison of scenario results, and evaluation of their consequences". The scenarios themselves are explorations of multiple plausible and coherent futures; they are not, however, meant to be accurate predictions of the future (Peterson, Cumming, and Carpenter 2003; Swart, Raskin, and Robinson 2004; Van Notten et al. 2003). Thus, scenario analysis facilitates systematic and creative thinking about possible futures in the face of complexity and uncertainty, with the intention of better understanding important drivers of change and evaluating strategies for responding to alternative future developments (Peterson, Cumming, and Carpenter 2003). Scenario analysis is particularly well-suited to questions of sustainable development because, on the one hand, it is amenable to the inclusive, participatory, dialoguestimulating processes necessary for dealing with the normative dimensions of sustainable development (Berkhout, Hertin, and Jordan 2002) and, on the other hand, is especially formulated to take into account the uncertainty that is an inherent feature of complex socialecological systems (Swart, Raskin, and Robinson 2004).

Scenario analysis can be applied to sustainability planning and policy in a number of ways, depending on the goal, process design and scenario content of a particular intervention or policy (Swart, Raskin, and Robinson 2004; Van Notten et al. 2003). The flexibility of scenario analysis stems in part from the variety of methodologies ${ }^{1}$ that exist for building and evaluating scenarios (Swart, Raskin, and Robinson 2004).

\subsection{Qualitative versus quantitative methodological approaches}

Among the variants of scenario analyses, one distinguishing feature is the extent to which the methodological approach is qualitative or quantitative in nature.

\footnotetext{
${ }^{1}$ Building on the careful work of Kosow (2015), we similarly adopt Hinkle's $(2008$, 44) sense of the terms 'methodology' and 'methodological approach' as the "specific configuration of methods, data and people involved in solving a problem".
} 
Qualitative scenarios describe possible futures in terms of narrative statements and visual symbols, and are typically produced in a workshop setting where experts and stakeholders can contribute different viewpoints about key drivers and future outcomes. Participatory qualitative scenarios enable the sharing and integration of multiple perspectives about the future, representing collective decades (or more) of experience with the relevant system and an array of expert and tacit knowledge residing in the mental models of scenario participants. As a result, qualitative scenarios yield a richer picture of the system and its working parts than could otherwise be achieved through singular mental or numerical models (Berkhout, Hertin, and Jordan 2002) and it is in this sense that qualitative scenarios are a wisdom-based tool. That is not to say, however, that qualitative scenarios are better than computer models at generating facts and 'predictions' about the future. Rather, these types of scenarios - to the extent that they encourage the communication, deliberation and integration of mental models - are valuable as a tool for social learning and developing a shared capacity for strategic planning (Berkhout, Hertin, and Jordan 2002; Vervoort et al. 2014).

However, the qualitative scenario methodology is also vulnerable to several weaknesses. For instance, the merit of participatory approaches largely depends on the composition of the scenario panel and the manner in which workshops are facilitated. Furthermore, many of the underlying assumptions that stem from the diverse and unstated mental models of participants are problematic for the 'traceability' (sensu Kosow 2015) of qualitative scenarios; that is, they lack explicitness, reproducibility, transparency, and accessibility for external actors.

In contrast, quantitative scenarios are numerical outputs generated by computer programmes or mathematical models. Quantitative scenarios address a need in policy and decision-making for numerical estimates of certain variables under alternate plausible futures. Compared to qualitative approaches, quantitative scenarios are seemingly traceable since many of the assumptions in mathematical models are explicit and offer a procedure which is reproducible. On the other hand, the accessibility and transparency of quantitative scenarios may be diminished for non-experts in modelling techniques (Alcamo 2008). Additionally, since mathematical models are necessarily abstractions of reality, the modelling process can be seen as parochial in the context of complex social-ecological systems (Kemp-Benedict 2004). Furthermore, the exactness of model outputs can give a misleading impression that more is known about the future than is actually the case (Alcamo 2008). 
Although there has, at times, been contention between the quantitative and qualitative traditions of scenario analyses, researchers have increasingly acknowledged their complementarity (Alcamo 2008; Kemp-Benedict 2004; Kok and van Delden 2009; Swart, Raskin, and Robinson 2004). Following the integration of qualitative and quantitative methodological elements in a number of high-profile international scenario exercises - including, amongst others, the IPCC's emission scenarios, the scenarios underpinning the Millennium Ecosystem Assessment, the recent set of Global Environmental Outlook scenarios produced by the United Nations, as well as the Shared Socioeconomic Pathways (SSPs) (see Riahi et al. 2017) - interest in 'hybrid' scenario methodologies has been mounting (Alcamo 2008; Swart, Raskin, and Robinson 2004; Kemp-Benedict 2004).

\subsection{Strengths and weaknesses of hybrid scenario approaches}

A well-known approach to hybrid scenario analysis is the 'story-and-simulation' (SAS) methodology proposed by Alcamo (2008). An ideal SAS procedure begins with the definition of the goal and scope of the scenarios. Next, a set of preliminary narrative storylines are developed by a panel of selected stakeholders and experts. Later, driving forces identified in the narrative storylines are quantified and used as inputs to the modelling process. A modelling team then computes relevant indicators for each of the scenarios. The SAS approach also recommends that the output indicators are reviewed by the scenario panel and revised if necessary, resulting in an iterative process of model and scenario refinement until modellers and panellist are satisfied. Lastly, the scenarios are distributed widely for general review before they are finalised and published.

Developing narrative scenarios before numerical modelling, as is the procedure in SAS, is thought to elicit the relative strengths of qualitative and quantitative methodologies for dealing with the respective 'complexity' and 'complicatedness' of social-ecological systems (KempBenedict 2004; Kemp-Benedict 2013). That is to say, preliminary qualitative scenario development encourages creative, multidimensional thinking and draws on the diversity of mental models provided by multi-stakeholder scenario panellists, while numerical modelling procedures are subsequently used to, amongst other things, serve as a 'reality check' by exposing contradictions and forcing clarification of elements in narrative storylines, numerically or graphically illustrate a particular storyline, and enhance the traceability of 
scenarios by encoding and formalizing key elements of the scenario exercise (Berkhout, Hertin, and Jordan 2002; Kemp-Benedict 2004).

However, a major weakness of hybrid scenario approaches is the conversion of linguistic assumptions embedded in narrative storylines to quantitative inputs for numerical modelling. Two interrelated hazards emerge from the conversion problem. First, there is a danger that the conversion process results in inconsistency between storyline assumptions and model parameters, potentially undermining in the credibility of the final scenarios (Kosow 2015). Second, there is the risk that procedures used to convert narrative assumptions to model parameters are not transparent or reproducible, thereby detracting from the traceability of the scenarios (Alcamo 2008; Kosow 2015).

To safeguard against these hazards, Alcamo (2008) calls for specific protocols to be used in the conversion process. In response to this call, methods such as Cross-Impact Balance and Simulation (CIBAS) (Kosow 2011) and Fuzzy Cognitive Mapping (FCM) (Kok 2009) have been proposed. Such methods have the potential to improve the traceability and consistency of SAS scenarios (e.g. Kosow 2015). However, due to the focus on quantifying drivers for simulation, applications of methods such as FCM tend to downplay the importance of 'soft' drivers (i.e. concepts that are hard to quantify, such as institutional and cultural factors) (Kok 2009; Kok and van Delden 2009). In addition, methods such as CIBAS and FCM are technically demanding and time-consuming and are therefore not always feasible for resourceconstrained government agencies, researchers, decision-makers and the like. In contrast, simpler methodological frameworks for addressing the conversion problem tend to be projectand model-specific (e.g. Capitani 2016, Vervoort et al. 2014).

Consequently, alternative protocols for addressing the conversion problem are needed. Such protocols need to be flexible enough to conform to a variety of modelling frameworks, while also being feasible for resource-constrained researchers, government agencies etc. who are best suited for applying hybrid scenario approaches in the context of practical work and urgent decision-making related to sustainable development. Additionally, these protocols need to address the potential bias against 'soft drivers' in final scenarios. We propose that the five capitals framework has the potential to enhance hybrid scenarios on both these counts. 


\section{The five capitals framework}

The analytical framework which we describe in this paper consists of five categories of capital assets. The five capitals provide a theoretically-grounded conceptual structure for systematically and holistically identifying and semi-quantifying relevant drivers of scenarios in the context of sustainable development. Before demonstrating how the five capitals framework can be used in the context of hybrid scenario approaches, we first explain what the five capitals are and how they relate to sustainable development.

\subsection{What are the 'five capitals'?}

In layman's terms, 'capital' is often understood in a financial accounting sense. That is, capital is thought of as the total value of real and financial assets owned by an entity, thus reflecting that entity's material wealth. Although limited, the latter conceptualization illustrates three essential features of what we mean by 'capital'. First, capital is a stock from which a flow of benefits (e.g. income) is derived, such as rental on machinery or interest on financial investments. Thus, since all production arises by putting capital to use, capital stocks comprise the productive base of the economy (Dasgupta 2015). Second, decisions about the relative proportion of immediate to delayed consumption (i.e. savings or investment) of benefit streams affect the size, and therefore the income-generating capacity, of the capital stock. In other words, some level of investment is required to sustain or expand the benefit generating capacity of a particular capital asset. Third, most forms of capital demonstrate some degree of substitutability as well as complementarity with other forms of capital.

Some economists now recognize a set of capital assets that extend well beyond financial and manufactured (also called produced) capital. In as early as the 1960s, the idea of 'human capital' was introduced to account for higher production in countries with better educated, experienced and healthy human resources (Schultz 1961). Later, in conjunction with the emergence of sustainable development in the late 1980s, the concept of 'natural capital' was used to account for the instrumental value of well-functioning ecological systems (Rees 1995). More recently, the notion of 'social capital' has been advanced in light of mounting evidence that social phenomena - such as trust, shared values, conventions, laws and social networks play an important role in mobilizing and organising economic production ${ }^{2}$ (Putnam 1993;

\footnotetext{
${ }^{2}$ Following Ostrom \& Ahn $(2009,8)$, we include under the rubric of social capital the "cultural, social and institutional aspects of communities of various sizes [which] jointly affect their capacity of dealing with collective-action problems". Therefore, we aggregate categories which are elsewhere referred to as 'cultural',
} 
Table 1: Five categories of capital assets

\begin{tabular}{|c|l|}
\hline $\begin{array}{c}\text { Category of Capital } \\
\text { Asset }\end{array}$ & \multicolumn{1}{c|}{ Description } \\
\hline Manufactured/ produced & Productive man-made material assets, such as machinery and infrastructure. \\
\hline Financial & $\begin{array}{l}\text { Financial assets that enable productive activity. Monetary savings, equity, and } \\
\text { government bonds are all examples of financial capital. }\end{array}$ \\
\hline Human & $\begin{array}{l}\text { Individual human assets, such as knowledge, health, skills and capabilities that } \\
\text { make people productive assets within the economy. }\end{array}$ \\
\hline Natural & $\begin{array}{l}\text { The quantity and quality of living and non-living natural resources which } \\
\text { produce ecosystem services that underpin economic activity and human well- } \\
\text { being. }\end{array}$ \\
\hline Social & $\begin{array}{l}\text { Features of social relationships that enable people to work together. Common } \\
\text { examples of social capital are cultural norms and national laws that enable } \\
\text { people to coordinate their activities within the economy. }\end{array}$ \\
\hline
\end{tabular}


Uphoff 2000). Thus, we arrive at the five capitals defined in Table 1 which provide the point of departure for the analytical framework presented in this paper. Ellis (2000) describes the same set of five capitals as assets in the sustainable livelihoods framework while, in other texts, the spectrum of capitals may be composed of more or less categories, reflecting a more or less disaggregated typology, but without any substantive differences to what we have described in Table 1. For example, Serageldin $(1996,188)$ asserts that there are "at least four kinds of capital", among which he aggregates financial and manufactured capital into 'man-made capital' (also called 'reproducible capital' elsewhere (e.g. Dasgupta 2015)).

Each of the categories in Table 1 demonstrate features of capital which we highlighted above: (i) they comprise the productive base of the economy and therefore, in aggregate, capture the overall wealth of a particular nation ${ }^{3}$ (Arrow et al. 2012a; Serageldin 1996; Dasgupta 2015) (ii) they require investments to remain productive over time and (iii) they are often partial complements and partial substitutes with one another (Serageldin 1996). (Also see Ostrom and Ahn (2009) and Uphoff (2000) for a discussion of how social capital in particular embodies these characteristics).

\subsection{A theoretical perspective on capital assets and sustainable development}

The five capitals provide a powerful conceptual and theoretical framework for thinking about sustainable development. In fact, increased recognition of a broader set of capital assets stems from long-standing debates about how to improve measurements of the wealth and development of nations - particularly with regards to the system of national accounting - and operationalize sustainable development (Arrow et al. 2004; Arrow et al. 2012b; Dasgupta 2009; Serageldin 1996). A notable contribution was made by a series of collaborations between economists and ecologists (Arrow et al. 2004; Arrow et al. 2012a; Arrow et al. 2012b) who sought to formalize the sustainable development concept in terms of wealth (a stock concept)

\footnotetext{
'knowledge' (in the sense of socially-held knowledge or knowledge technology; i.e. distinct from knowledge that constitutes human capital) and 'institutional' capital (e.g. Dasgupta 2015). Using an aggregated version of social capital is in keeping with the aggregate characteristic of other capital asset classes (such as exhaustible, replenishable and renewable natural resources falling under the class of natural capital, for instance).

${ }^{3}$ Given that categories of capitals are being used here as a type of conceptual filing system, they are applicable regardless of the GDP/ level of development of a region or country.
} 
and to establish the theoretical criteria for achieving it. This approach differed to previous attempts at formalizing sustainable development which emphasized net national product (NNP) and consumption (flow variables that loosely represent the income and expenditure of a nation) (see Dasgupta and Mäler 2000). For convenience, we refer to the former as the 'wealth' approach and the latter as the 'income' approach to conceptualizing and operationalizing sustainable development. While the income approach relies on restrictive assumptions about the optimality of the economy and the convexity of production possibility sets, the wealth approach has been extended to include the more realistic terms of non-optimal economies and non-convexity respectively (Dasgupta and Mäler 2000).

In essence, the wealth approach equates the concept of sustainability with ensuring that future generations have the same consumption opportunities as present generations (Arrow et al. 2012a; Chambers and Conway 1992; Serageldin 1996). Capital assets play a central role this formulation in so far as each generation's consumption opportunities are determined by the total stock of capital assets available to them. More specifically, this approach suggests that development is sustainable if comprehensive wealth (i.e. the total value of capital assets, as determined by their shadow prices) per capita does not decline at any point in the future (Arrow et al. 2012a). Not only is this criterion more practical than an income approach to sustainable development (Dasgupta 2009), but it also complements the widely accepted interpretation of sustainable development as "development that meets the needs of the present without compromising the ability of future generations to meet their own needs" (WCED 1987, 8).

\subsection{Some comments on a capitalistic approach}

The capitalistic thinking embedded in the wealth approach to sustainable development brings to light three important points.

The first point pertains to a number of related objections that capitalistic thinking is reductionist, that it commodifies aspects of society and nature, and that it represents attempts by economists to 'colonize' topics from other disciplines (e.g. Fine 2002). Although it is beyond the scope of this paper to address these concerns in detail, we wish to point out that the shadow prices embedded in the comprehensive wealth computation reflect the social value of capital assets, not market prices. In theory, shadow prices are a measure of how changes in capital stocks affect human well-being (Dasgupta 2015). Therefore, shadow prices include a 
broader notion of value than those usually associated with market prices. Furthermore, the alternative - that is, excluding human, social and natural capital from the set of capital assets - may result in these stocks being entirely disregarded and given an effective value of zero in decision-making processes.

Secondly, 'soft' concepts (such as those embedded in human and social capital) are acknowledged as real assets that have actual (and indeed, substantial) impacts on genuine wealth and its conversion to human well-being ${ }^{4}$; this, despite earlier objections by some economists (e.g. Solow 1999) that such concepts ought not to be considered as capital assets on the grounds that they are challenging to define, intangible, and difficult to measure quantitatively. Indeed, all categories of capital assets - even tangible assets - exhibit problems of delineation and measurement (Ostrom and Ahn 2009).

This brings us to the third point, which is that the inclusion of financial and manufactured capital alone in the traditional system of national accounts has led to perverse incentives to over-extract exhaustible resources, degrade ecosystems, and underinvest in crucial factors of wealth creation such as education, human health, and systems of law. Although there is no doubt that measuring and accounting for intangible stocks is challenging, including them in the set of capital assets ought to, at a minimum, (i) change the way that nation states perceive growth, development and wealth and (ii) improve the figures of genuine wealth and sustainable development, even if only by using rough proxies (Dasgupta 2015). Furthermore, as demonstrated in the case of social capital (Grootaert and van Bastelaer 2001), formally recognising the 'soft' capitals in the measurement of wealth can generate an impetus for researching and refining appropriate proxy measures.

In sum, the types of capital assets to which we refer in this paper (manufactured, financial, natural, human, and social capital) underpin a broad conceptualization of wealth which is intimately related to what sustainable development means and how it can be achieved. Although the 'soft' capitals are hard to define and measure, they too are essential to the wellbeing of current and future generations. Thus, a framework based on the five capitals is particularly well-suited to the analysis of scenarios concerning sustainable development, and

\footnotetext{
${ }^{4}$ In particular, social capital can be thought of as an enabling asset working as part of total factor productivity, just as in the case of technology (Dasgupta 2015; Dasgupta 2009).
} 
perhaps even more so in the case of hybrid scenario approaches which similarly incorporate important, but hard-to-quantify drivers of plausible futures.

\section{Empirical application of the five capitals framework}

\subsection{Background and relevance of the South African case study}

During the commodity super cycle between 2010-2015 (Louw 2017; Westhoff 2010), various agricultural organisations had voiced concerns about the rapid expansion in mining activity and increased land acquisition by mining companies of large tracts of high-potential agricultural land in South Africa; although little was known at the time about the extent of landuse conversion or the long-term implications thereof for, amongst other things, employment, food security, environmental degradation, and sustainable development (BFAP, 2012). Seeking clarity on this issue, the South African Maize Trust commissioned a study to engage key stakeholders in a dialogue about the extent and trajectory of competition for natural resources between mining and agriculture in South Africa, as well as to identify areas of possible collaboration and practical interventions that could support sustainable resource use between the two sectors. The analytical approach used in the study relied heavily on the development and use of hybrid scenarios to explore possible futures of the mining and agricultural sectors in South Africa. Seeking to integrate the insights of expert-generated qualitative scenarios with economic models, the authors encountered the challenge of converting narrative storylines into numerical parameters. The five capitals framework emerged as a practical solution to this issue.

The aim of this paper is methodological in nature. That is, our focus is communicating how the five capitals framework was used to overcome the conversion problem in a situation where resource constraints limited the feasibility of other technically rigorous solutions. Therefore, the broader research objectives, results, and recommendations of the study are tangential to this paper (details are publicly available in the project report (see BFAP, 2015)). Also, we acknowledge that the empirical application which we describe here is imperfect on multiple counts; retrospectively, we have discovered that there are several ways that the application of the framework could have been enhanced (issues which we discuss further in Section 5). Aware of this caveat, we therefore present the empirical application of the five capitals framework to illustrate how the framework was applied in the South African case study, but also as a starting 
point for Section 5, in which we discuss how the framework could potentially be applied in other hybrid scenario analyses.

\subsection{Approach and selected results}

The hybrid scenario methodology was implemented via a three-phased approach (as depicted in Figure 1), loosely corresponding pre-workshop preparation, narrative scenario development via a scenario workshop, and quantitative scenario modelling.

An important element of phase 1 was the identification of scenario panellists, which was done via a process closely resembling chain sampling. Specifically, panellists were identified based on recommendations by experts, industry organisations, and government departments. Ultimately, an effort was made to invite key role players and experts who are most insightful about the respective dynamics of the agricultural and mining sectors, as well as their influence on the economy and natural environment. A corresponding trade-off was that some of these high-profile participants were unavailable to participate in multiple rounds of workshops. The final panel comprised representatives from a variety of organisations, with an equal representation between the agricultural and mining sectors respectively (Table 2). Phase 1 also included a review of the available literature and preparation of an 'information pack' which was disseminated to panellists to communicate the rationale for the study and the specific goals of the scenario session.

Phase 2 consisted of a one-day scenario session facilitated by a scenario planning and futures practitioner. Initially, panellists were encouraged to jointly define the focal issue for the session, thus narrowing the parameters for scenario development in order to produce stories that are as relevant as possible. In discussing the focal issue associated with natural resources, agriculture and mining in South Africa, participants highlighted a broad spectrum of concepts ranging from employment and export earnings to social stability and food and energy security. Panellists agreed that not only do both the mining and agricultural sectors play a critical role in the South African economy, but that they are also interwoven in the political and social 


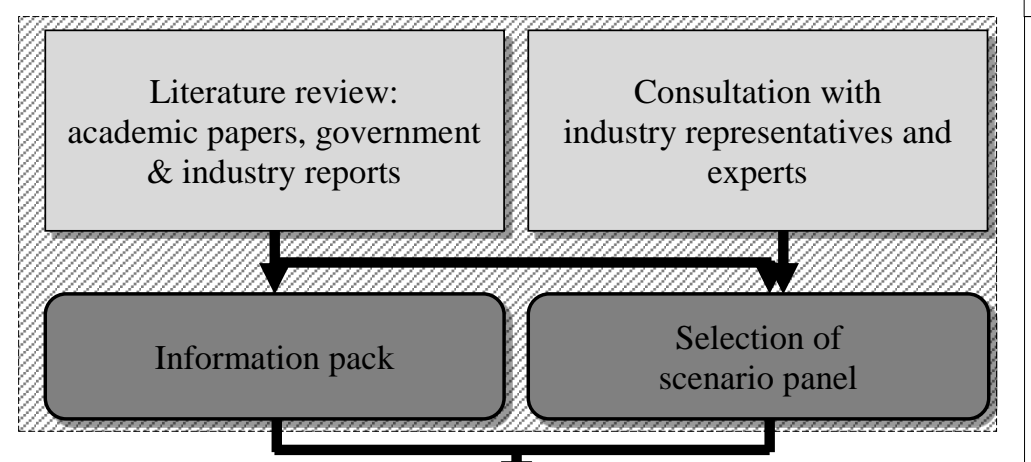

Phase 2

Phase 3

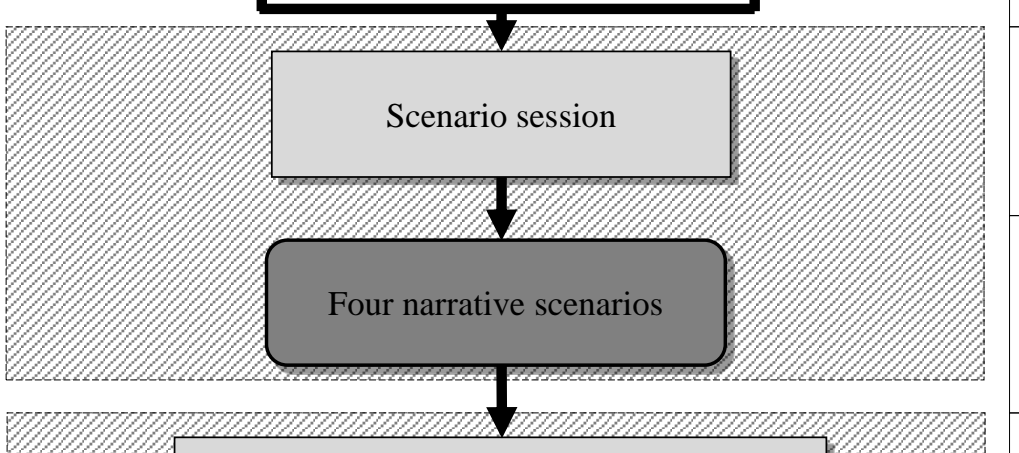
quantitative model inputs using the five capitals framework

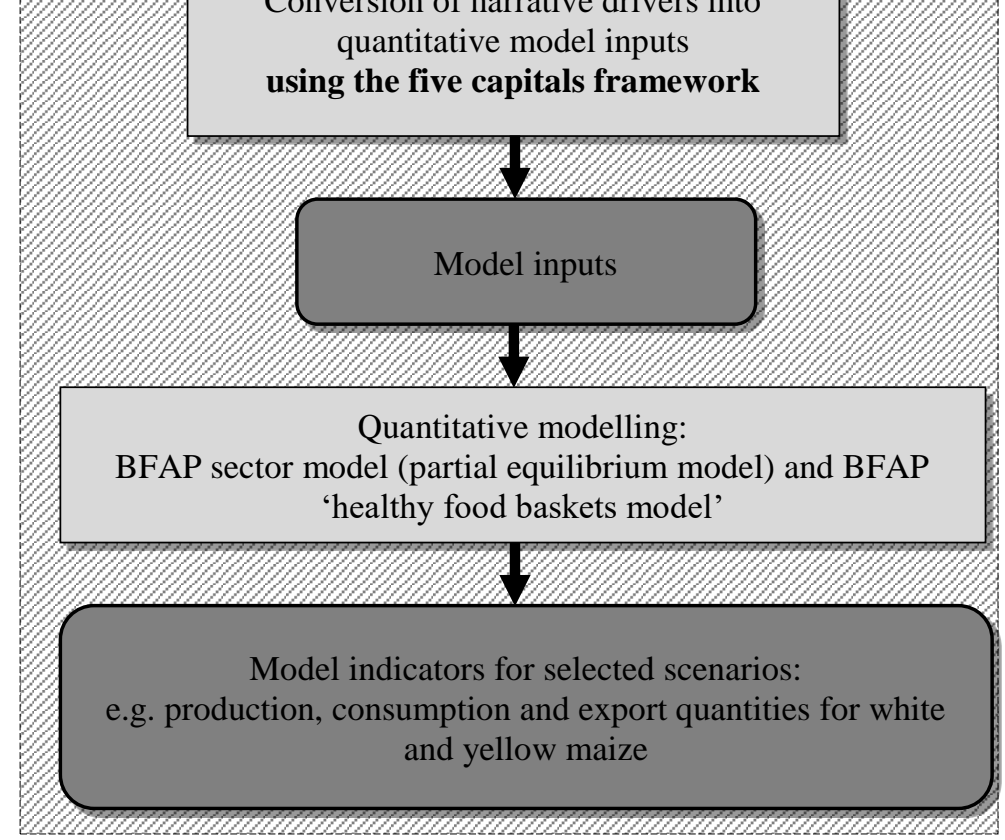

\section{Further Information}

Further details about the output of the literature review, information pack and composition of the scenario panel are provided in BFAP (2015).

A detailed report about the scenario workshop is laid out in BFAP (2015, Appendix A)

Expanded storylines for each of the scenarios are available in Appendix A.1.

Additional information about how the five capitals framework was used to convert narrative storylines into model inputs is available in Appendix A.2.

BFAP $(2016 ; 2015)$ also offer a more detailed description of the types of models that were used in the study.

Selected quantitative results are presented in Appendix A.3.

\section{Figure 1: Phases of scenario analysis in the South African case study}


Table 2: Composition of the scenario panel by organisation type

\begin{tabular}{|c|c|c|c|c|}
\hline \multirow{2}{*}{ Organisation Type } & \multirow{2}{*}{$\begin{array}{c}\text { Number of } \\
\text { Participants }\end{array}$} & \multicolumn{3}{|c|}{ Sector Represented } \\
\cline { 3 - 5 } & 6 & Agriculture & Mining & Other $^{\text {(a) }}$ \\
\hline Government & 6 & $\mathrm{X}$ & $\mathrm{X}$ & $\mathrm{X}$ \\
\hline Academic & 7 & $\mathrm{X}$ & $\mathrm{X}$ & $\mathrm{X}$ \\
\hline Industry & 4 & & $\mathrm{X}$ & \\
\hline Consulting & 6 & $\mathrm{X}$ & $\mathrm{X}$ & $\mathrm{X}$ \\
\hline Non-profit & 29 & 10 & 10 & $\mathrm{X}$ \\
\hline Total & 6 & & 9 \\
\hline
\end{tabular}

(a) Other sectors represented include: natural resources and environment (specifically, biodiversity, water and land-rehabilitation), macroeconomic and public policy. 
fabric of South Africa's past and present circumstances. Therefore, panellists decided that competition between mining and agriculture for natural resources imprints on a larger issue, which they expressed in terms of 'national security'. In this case, 'national security' was defined in a broad sense, capturing aspects such as "happy citizens, employment, no poverty, a transformed society and economy, food security and a sustainable natural resource base" (BFAP, 2015, p. 90). Given the latter definition, the scenario panel defined the unit of analysis as "the contribution and coexistence of mining and agriculture towards ensuring national security in 2030-35".

Subsequently, drawing on an 'intuitive logics' technique (Bradfield et al. 2005), key uncertainties were discussed and prioritized by plotting them according to their perceived levels of uncertainty and impact respectively. Thereafter, a double uncertainty matrix was used to develop four narrative scenarios. The two orthogonal dimensions chosen for the double uncertainty matrix included 'commodity prices' (ranging from 'low' to 'high'; representing the price environment for both hard and soft commodities) and 'governance' (ranging from 'poor' to 'excellent'; describing the intent and capability of organisations and the state to implement policy, as well as exercise stewardship over natural resources $)^{5}$. Abridged versions of the resultant narrative storylines are depicted in Figure 2 (expanded descriptions of the storylines are also available in Appendix A.1).

In phase 3 , the scenario team (i.e. the team of researchers driving the scenario development process) converted the narrative scenarios resulting from phase 2 into input parameters for quantitative modelling ${ }^{6}$ by using the five capitals framework. Firstly, narrative storylines were interpreted by describing the state of each capital asset under each scenario (Table 3). In order to perform this interpretation, narrative storylines (and the underlying discussions, as recorded in the scenario discussion report appended to BFAP (2015)) were relied on as much as possible.

\footnotetext{
${ }^{5}$ Key uncertainties discussed also included disruptive changes, including, among others, climate change impacts on mining and agriculture, game-changing technology breakthroughs, and regional and global political trade relations (see appendices of BFAP, 2015). However, these disruptive factors were deemed by the scenario panel to be less important than governance and prices, especially during the 2035 timeframe.

${ }^{6}$ To quantitatively depict the effect of different plausible futures on the South African agricultural sector, BFAP's 'sector model' was used to model the impacts of scenarios on agricultural production, consumption, prices and trade. Additionally, BFAP's 'healthy food baskets model' was used to illustrate the potential impact of scenarios on food affordability. Further information regarding these models can be found in BFAP $(2016 ; 2015)$.
} 


\section{HIGH COMMODITY PRICES}

\begin{tabular}{|c|c|c|}
\hline & $\begin{array}{l}\text { BLOOD DIAMOND } \\
\text { It's a dog-eat-dog world out there with } \\
\text { cutthroat tactics when it comes to } \\
\text { producing the 'yellow gold', be it maize } \\
\text { or mineral. For a while the farmers had } \\
\text { the upper hand because of food security } \\
\text { concerns, but corruption and mining are } \\
\text { a match made in heaven. Mind you, the } \\
\text { panga swings... any more food price } \\
\text { hikes, and riots will lead to a rethink. } \\
\text { Pity the roads are unusable, never mind } \\
\text { the water... }\end{array}$ & $\begin{array}{l}\text { THE SOUND OF MUSIC } \\
\text { The hills are truly alive with the sound } \\
\text { of music as all stakeholders 'sing from } \\
\text { the same hymn sheet'. There is fierce } \\
\text { competition for land and mega-bucks to } \\
\text { be made, but miners, farmers, } \\
\text { government and investors all play by the } \\
\text { rulebook; plus, play nice with one } \\
\text { another. Best of all is the brilliant } \\
\text { management of scarce water, combined } \\
\text { with the solid shift to renewable energy. } \\
\text { It's time to yodel... wait, let's make that } \\
\text { ululate! }\end{array}$ \\
\hline ERANCE & $\begin{array}{l}\text { GOTHAM CITY } \\
\text { You don't need to be a Batman fan to } \\
\text { recognise this dark and dysfunctional } \\
\text { setting. The mining and agricultural } \\
\text { sectors are bleeding profits, people and } \\
\text { principles. Not that this makes the } \\
\text { headlines, though. The crisis is all about } \\
\text { out-of-control corruption, service } \\
\text { delivery protests on steroids and 'water } \\
\text { shedding' in full swing. Some land lies } \\
\text { fallow, some land degrades and some } \\
\text { land is up for grabs, just because it is... }\end{array}$ & $\begin{array}{l}\text { BEAUTY AND THE BEAST } \\
\text { The transformation and NDP pay-off } \\
\text { has properly kicked in, and, as expected, } \\
\text { some old (fashioned) mining and } \\
\text { agricultural stalwarts (aka the beasts) } \\
\text { haven't survived into the new, albeit } \\
\text { tough, era. If only the commodity cycle } \\
\text { would tick up. It is punishing to make a } \\
\text { profit, especially when policy, and even } \\
\text { monetary, support goes only to those } \\
\text { that work together and deliver the true } \\
\text { triple bottom-line. Wilderness areas are } \\
\text { a beauty to behold, though. }\end{array}$ \\
\hline
\end{tabular}

LOW COMMODITY PRICES

EXCELLENT GOVERNANCE

\section{Figure 2: Short storyline descriptions of the four scenarios in the South African case study}


Table 3: State of the five capitals within each of the scenarios

\begin{tabular}{|c|c|c|c|c|c|}
\hline & \multicolumn{5}{|c|}{ Category of Capital Asset } \\
\hline Scenario & Financial & Social & Human & Manufactured & Natural \\
\hline $\begin{array}{c}\text { Sound of Music } \\
\text { (Excellent Governance, } \\
\text { High Prices) }\end{array}$ & $\begin{array}{l}\text { Ample and readily } \\
\text { available finance }\end{array}$ & $\begin{array}{c}\text { Generally trusting, } \\
\text { cooperative and resilient } \\
\text { society }\end{array}$ & $\begin{array}{l}\text { Highly skilled and healthy } \\
\text { workforce }\end{array}$ & $\begin{array}{l}\text { Sufficient and well- } \\
\text { maintained infrastructure }\end{array}$ & $\begin{array}{c}\text { Enhanced ecosystems and } \\
\text { healthy, well-managed } \\
\text { resource stocks }\end{array}$ \\
\hline $\begin{array}{l}\text { Beauty and the Beast } \\
\text { (Excellent Governance, } \\
\text { Low Prices) }\end{array}$ & $\begin{array}{l}\text { Moderate and stable levels } \\
\text { of finance }\end{array}$ & $\begin{array}{c}\text { Good rapport between } \\
\text { formal sectors (business } \\
\text { and government) enabling } \\
\text { coordination for economic } \\
\text { development }\end{array}$ & $\begin{array}{c}\text { Moderately skilled } \\
\text { workforce supported by } \\
\text { functional health services } \\
\text { and access to basic } \\
\text { education }\end{array}$ & $\begin{array}{l}\text { Insufficient but well- } \\
\text { maintained infrastructure }\end{array}$ & $\begin{array}{l}\text { Functioning ecosystems } \\
\text { with most resource stocks } \\
\text { being used sustainably }\end{array}$ \\
\hline $\begin{array}{c}\text { Blood Diamond } \\
\text { (Terrible Governance, } \\
\text { High Prices) }\end{array}$ & $\begin{array}{l}\text { Moderate but volatile } \\
\text { levels of finance }\end{array}$ & $\begin{array}{l}\text { Social cohesion amongst a } \\
\text { select few which drives a } \\
\text { corrupt but active } \\
\text { economy }\end{array}$ & $\begin{array}{l}\text { Moderately skilled } \\
\text { workforce hampered by } \\
\text { poor health services and } \\
\text { limited access to basic } \\
\text { education }\end{array}$ & $\begin{array}{l}\text { Disparate supply and } \\
\text { quality of infrastructure } \\
\text { across regions }\end{array}$ & $\begin{array}{l}\text { Partially-functioning } \\
\text { ecosystems and } \\
\text { unsustainable depletion of } \\
\text { resource stocks }\end{array}$ \\
\hline $\begin{array}{c}\text { Gotham City } \\
\text { (Terrible Governance, } \\
\text { Low Prices) }\end{array}$ & $\begin{array}{l}\text { Low levels of available } \\
\text { finance }\end{array}$ & $\begin{array}{l}\text { Social disarray which } \\
\text { hinders economic activity }\end{array}$ & $\begin{array}{l}\text { Unskilled, poorly educated } \\
\text { workforce with almost no } \\
\text { access to public health } \\
\text { services }\end{array}$ & $\begin{array}{l}\text { Insufficient and neglected } \\
\text { infrastructure }\end{array}$ & $\begin{array}{c}\text { Degraded ecosystems and } \\
\text { rapid depletion of resource } \\
\text { stocks }\end{array}$ \\
\hline
\end{tabular}


Table 4: Justifications for the state of capital assets in the Sound of Music scenario, as per the language and tone of the relevant storyline

\begin{tabular}{|c|c|c|}
\hline $\begin{array}{c}\text { Category of } \\
\text { Capital Asset }\end{array}$ & State & Justification $^{(a)}$ \\
\hline Financial & $\begin{array}{l}\text { Ample and readily } \\
\text { available finance }\end{array}$ & $\begin{array}{c}\text { A high commodity price environment (driven by "consistently strong demand from China, India... and the burgeoning African } \\
\text { economies") result in favourable returns and increased opportunities for investment. Additionally, excellent systems of governance } \\
\text { confer a "stable and predictable policy environment" which augments investor confidence. As a result, there is ample and readily } \\
\text { available finance, and "investment and expansion is rife and on everybody's radar". High commodity prices also augment government } \\
\text { revenue via taxes and royalty payments. Consequently, treasury is in a good position to finance strategic and prudent public } \\
\text { investments (b). }\end{array}$ \\
\hline Social & $\begin{array}{l}\text { Generally trusting, } \\
\text { cooperative and } \\
\text { resilient society }\end{array}$ & $\begin{array}{l}\text { There is a "solid track record of cooperation... and working together for mutual benefit and the greater good". To deal with resource } \\
\text { constraints, "farmers and miners have been exploring and innovating together around re-use, recycling and win-win solutions". }\end{array}$ \\
\hline Human & $\begin{array}{l}\text { Highly skilled and } \\
\text { healthy workforce }\end{array}$ & $\begin{array}{l}\text { Prudent, coordinated governance, coupled with a drive towards transformation (c) ("key players in both sectors drove transformation } \\
\text { hard") result in public and private funds being channelled towards education and health care services. At the same time, favourable } \\
\text { domestic circumstances (underpinned by a booming economy, stable and predictable policy environment, cooperative society, well- } \\
\text { funded and -run public institutions, and a pleasant and clean natural environment) retain educated and skilled individuals in the South } \\
\text { African economy, thereby positively reinforcing the production of an educated and skilled workforce }\end{array}$ \\
\hline Manufactured & $\begin{array}{l}\text { Sufficient and well- } \\
\text { maintained } \\
\text { infrastructure }\end{array}$ & $\begin{array}{l}\text { Demand (driven by "consistently strong demand from China, India... and the burgeoning African economies"), coupled with ample } \\
\text { and readily available finance (see justifications for financial capital) facilitate widespread physical investments ("investment and } \\
\text { expansion is rife and on everybody's radar"). Additionally, the strong position of the fiscus augments the expansion in infrastructure, } \\
\text { especially because of the prudent and transformative policy agenda. Business and government come together to facilitate the } \\
\text { expansion in infrastructure: "The fact that key players drove transformation hard, and that there were and still are excellent relations } \\
\text { in place with effective technocrats, made the seemingly impossible actually happen. Of course it was all helped along by the strategic } \\
\text { role that both [the mining and agricultural] industries played in the public-private partnership infrastructure rollout". }\end{array}$ \\
\hline Natural & $\begin{array}{l}\text { Enhanced ecosystems } \\
\text { and healthy, well- } \\
\text { managed resource } \\
\text { stocks }\end{array}$ & $\begin{array}{c}\text { Sustainable resource use and strategic investments in renewable energy and rehabilitation or maintenance of important ecosystems' } \\
\text { (e.g. major watersheds) are prioritised by "South Africa's excellent governance framework for scarce resources, energy and water in } \\
\text { particular". }\end{array}$ \\
\hline
\end{tabular}

(a) Quotes are taken from the expanded scenario storylines (available in Appendix A, section A.4)

(b) This interpretation is not directly reflected in the text of the storyline, but is implied through the reference to the strong nature of public management (e.g. "South Africa's well-designed and-managed basic income protection system...excellent governance framework for scarce resources”, as well as references to public investment (e.g. "publicprivate partnership infrastructure rollout").

(c) Although not well defined, the term 'transformation' used in the South African context typically refers to socioeconomic transformation as a means of addressing the legacies of apartheid (c.f. Clarke and Bassett 2016). A major component of the transformation rhetoric is associated with wider access to education and health care; most recently, a wave of contentious student protests has highlighted the issue of transformation in higher education in South Africa. 
For this reason, the assumed states of the five capitals, as represented in Table 3, should be seen in the context of the language and tone of the storylines (i.e. they are not simply the product of 'prices' and 'governance', as per economic or social theory or empirical observation). Table 4 uses the 'Sound of Music' scenario to demonstrate the underlying process and reasoning involved in deriving the states of the five capitals.

Next, to distil assumptions for quantitative modelling, plausible consequences of the state of the five capitals were formulated in terms of ordinal measures (e.g. high, medium, low) for key elements of each capital asset (Table 5). Thereafter, ordinal measures captured in Table 5 were used to quantify macroeconomic assumptions required for modelling. The process of converting the ordinal measures to numerical model parameters relied on the best guesses of members of the scenario team who, owing to their long-standing expertise in agricultural commodity analysis (e.g. BFAP, 2016), were considered to be experts well-suited to the task. To clarify how this was achieved, Appendix A.2 summarizes the numerical model parameters that were used (Table A.1) as well as the underlying reasoning that was used in deriving these model assumptions (Table A.2) as per the rationale laid out in Table 5. In addition - to provide a more detailed example than the overview presented in Appendix A.2 - Box 1 uses the 'Sound of Music' scenario to provide an illustration of the semi-quantification process in translating the scenario's narratives into parameters for modelling.

Appendix A.3 gives an overview of the some of the key results obtained from the modelling exercise, as well as a brief description of how they were used. We have included these results to augment the reader's understanding of how the five capitals framework was applied in the case study, although we reemphasize that these specific results are not the focus of this paper. 
Table 5: Non-exhaustive, plausible consequences of the state of the five capitals in each scenario ${ }^{1}$

\begin{tabular}{|c|c|c|c|c|c|c|}
\hline \multirow[b]{2}{*}{ Scenario } & \multicolumn{5}{|c|}{ Category of Capital Asset } & \multirow{2}{*}{$\begin{array}{c}\text { General Characteristics of } \\
\text { Scenario }\end{array}$} \\
\hline & Financial & Social & Human & Manufactured & Natural & \\
\hline $\begin{array}{c}\text { Sound of } \\
\text { Music } \\
\text { (Excellent } \\
\text { Governance, } \\
\text { High Prices) }\end{array}$ & $\begin{array}{l}\text { - Strong and steady } \\
\text { economic growth } \\
\text { - High levels of } \\
\text { aggregate investment, } \\
\text { including foreign direct } \\
\text { investment } \\
\text { - Prudent public } \\
\text { investments by } \\
\text { government and public- } \\
\text { private partnerships, } \\
\text { resulting in: improved } \\
\text { provision and } \\
\text { accessibility of basic } \\
\text { education and health } \\
\text { care services; } \\
\text { rehabilitation of } \\
\text { degraded systems }\end{array}$ & $\begin{array}{l}\text { - Excellent } \\
\text { coordination and } \\
\text { cooperation between } \\
\text { different economic } \\
\text { sectors and sections } \\
\text { of society } \\
\text { - Low crime combined } \\
\text { with a general sense } \\
\text { of security } \\
\text { - Widespread support } \\
\text { for governance } \\
\text { structures } \\
\text { - Functional and stable } \\
\text { land transactions }\end{array}$ & $\begin{array}{l}\text { - Universal access to } \\
\text { high quality } \\
\text { education } \\
\text { - Improved capacity, } \\
\text { particularly in the } \\
\text { knowledge } \\
\text { economy } \\
\text { - Invigorated R\&D } \\
\text { and technological } \\
\text { innovation } \\
\text { - High labour } \\
\text { absorption rate } \\
\text { leading to increased } \\
\text { employment }\end{array}$ & $\begin{array}{l}\text { - Improved } \\
\text { infrastructure and } \\
\text { maintenance thereof, } \\
\text { including roads, } \\
\text { water, transport, and } \\
\text { communication } \\
\text { - Improved provision } \\
\text { of basic services, } \\
\text { especially to the poor }\end{array}$ & $\begin{array}{l}\text { - Rehabilitation of } \\
\text { degraded ecosystems, } \\
\text { thereby enhancing } \\
\text { ecosystem services } \\
\text { and ecological } \\
\text { resilience } \\
\text { - Reduced pollution } \\
\text { - Large-scale transition } \\
\text { to renewable energy }\end{array}$ & $\begin{array}{l}\text { - Stable and predictable policy } \\
\text { environment } \\
\text { - A high commodity price } \\
\text { environment provides ample and } \\
\text { readily available finance and } \\
\text { revenue, which in turn bolster } \\
\text { the ability of the fiscus to } \\
\text { provide public goods and } \\
\text { services } \\
\text { - Responsible, coordinated } \\
\text { governance promotes strategic } \\
\text { and prudent public spending } \\
\text { - Sustainable use of resources } \\
\text { and sound land-use planning }\end{array}$ \\
\hline $\begin{array}{c}\text { Beauty and } \\
\text { the Beast } \\
\text { (Excellent } \\
\text { Governance, } \\
\text { Low Prices) }\end{array}$ & $\begin{array}{l}\text { - Steady but moderate } \\
\text { economic growth (with } \\
\text { most of the growth } \\
\text { coming from non- } \\
\text { primary sectors) } \\
\text { - Subdued investment, } \\
\text { with government } \\
\text { spending driving key } \\
\text { public investments in } \\
\text { infrastructure, } \\
\text { education, healthcare } \\
\text { and renewable energy }\end{array}$ & $\begin{array}{l}\text { - Collaborative society, } \\
\text { working together in } \\
\text { order to stay afloat in } \\
\text { tough times } \\
\text { - Moderate crime } \\
\text { levels } \\
\text { - General support for } \\
\text { governance structures } \\
\text { - Some sensible land } \\
\text { transactions which } \\
\text { facilitate sound land- } \\
\text { use planning }\end{array}$ & $\begin{array}{l}\text { - Widespread access } \\
\text { to healthcare of } \\
\text { varying quality } \\
\text { - Widespread access } \\
\text { to good quality } \\
\text { basic education } \\
\text { - Subdued R\&D and } \\
\text { technological } \\
\text { innovation } \\
\text { - Increased } \\
\text { employment rate via } \\
\text { economic activity in } \\
\text { non-primary sectors }\end{array}$ & $\begin{array}{l}\text { - Well maintained } \\
\text { infrastructure, } \\
\text { however not } \\
\text { expanding and } \\
\text { stimulating new } \\
\text { growth opportunities } \\
\text { - Slowly improving } \\
\text { basic service } \\
\text { provision }\end{array}$ & $\begin{array}{l}\text { - Some investments in } \\
\text { rehabilitation of } \\
\text { degraded ecosystems } \\
\text { - Some pollution } \\
\text { control measures in } \\
\text { place } \\
\text { - Adequate provision } \\
\text { of ecosystem services } \\
\text { - Some adoption of } \\
\text { renewable energy }\end{array}$ & $\begin{array}{l}\text { - Stable and predictable policy } \\
\text { environment } \\
\text { - Low commodity prices result in } \\
\text { a relative increase in the } \\
\text { economic contribution of } \\
\text { secondary and tertiary sectors } \\
\text { versus that of primary sectors } \\
\text { - Public and private sectors face } \\
\text { budgetary constraints in a low } \\
\text { price environment } \\
\text { - Environmental sustainability is } \\
\text { prioritized but is limited by } \\
\text { constrained budgets }\end{array}$ \\
\hline
\end{tabular}

${ }^{1}$ The impact of each scenario on indicators including economic growth, investment status, governance perceptions, access to public services, crime rate, rate and manner of land transactions, research and development status, status of infrastructure, supply of ecosystem services, energy sources is describe. 


\begin{tabular}{|c|c|c|c|c|c|c|}
\hline $\begin{array}{c}\text { Blood } \\
\text { Diamond } \\
\text { (Terrible } \\
\text { Governance, } \\
\text { High Prices) }\end{array}$ & $\begin{array}{l}\text { - Generally low and } \\
\text { sporadic economic } \\
\text { growth } \\
\text { - Squandering of tax } \\
\text { revenue by public } \\
\text { organisations } \\
\text { - Volatile investments } \\
\text { favour a few sectors, } \\
\text { especially primary } \\
\text { sectors due to high } \\
\text { commodity prices }\end{array}$ & $\begin{array}{l}\text { - Rampant corruption } \\
\text { - High levels of crime } \\
\text { - Some land } \\
\text { transactions through } \\
\text { informal land markets }\end{array}$ & $\begin{array}{l}\text { - Unequal access to } \\
\text { education } \\
\text { - Increased } \\
\text { unemployment rate } \\
\text { - Restricted access to } \\
\text { healthcare } \\
\text { - Limited and } \\
\text { privately funded } \\
\text { R\&D focussing on a } \\
\text { few lucrative } \\
\text { opportunities }\end{array}$ & $\begin{array}{l}\text { - Maintenance of } \\
\text { infrastructure mostly } \\
\text { abandoned (but } \\
\text { maintained in some } \\
\text { locations, aiding a } \\
\text { select few in } \\
\text { mobilising economic } \\
\text { activity) } \\
\text { - Limited delivery of } \\
\text { basic services }\end{array}$ & $\begin{array}{l}\text { - Unsustainable } \\
\text { exploitation of natural } \\
\text { resources } \\
\text { - Lack of a diversified } \\
\text { energy mix and } \\
\text { ongoing crisis } \\
\text { management in } \\
\text { energy supply } \\
\text { - Widespread pollution } \\
\text { and degradation of } \\
\text { ecosystems } \\
\text { - Constrained } \\
\text { ecosystem services } \\
\text { hamper human well- } \\
\text { being and restrict } \\
\text { economic activity }\end{array}$ & $\begin{array}{l}\text { - Rampant corruption } \\
\text { - Inconsistent implementation of } \\
\text { government policies, resulting in } \\
\text { an unpredictable policy } \\
\text { environment } \\
\text { - High levels of inequality } \\
\text { - High commodity prices, leading } \\
\text { to significant economic } \\
\text { contribution by primary sectors } \\
\text { - Distrusting, lawless society } \\
\text { - Passivity towards } \\
\text { environmental challenges }\end{array}$ \\
\hline $\begin{array}{l}\text { Gotham City } \\
\text { (Terrible } \\
\text { Governance, } \\
\text { Low Prices) }\end{array}$ & $\begin{array}{l}\text { - Low economic growth } \\
\text { - Squandering of tax } \\
\text { revenue by public } \\
\text { organisations } \\
\text { - Little/no investment, } \\
\text { debilitating the smallest } \\
\text { potential for growth }\end{array}$ & $\begin{array}{l}\text { - Divided, fearful } \\
\text { sections of society } \\
\text { - High crime levels } \\
\text { - Widespread } \\
\text { lawlessness and no } \\
\text { sense of security } \\
\text { - Non-existent land } \\
\text { transactions (land } \\
\text { grabs) }\end{array}$ & $\begin{array}{l}\text { - Limited access to } \\
\text { basic education } \\
\text { - Increased } \\
\text { unemployment rate } \\
\text { - Diminished } \\
\text { capacity for R\&D } \\
\text { - Scarce availability } \\
\text { of healthcare } \\
\text { services }\end{array}$ & $\begin{array}{l}\text { - No new large capital } \\
\text { projects being } \\
\text { undertaken } \\
\text { - Totally neglected and } \\
\text { derelict infrastructure } \\
\text { - Inadequate provision } \\
\text { of basic services }\end{array}$ & $\begin{array}{l}\text { - Depletion of natural } \\
\text { resources further } \\
\text { exacerbating limited } \\
\text { access to basic } \\
\text { services } \\
\text { - Heavily polluted } \\
\text { environment } \\
\text { - Rampant degradation } \\
\text { - Failing ecosystem } \\
\text { services resulting in } \\
\text { severely constrained } \\
\text { economic activity and } \\
\text { vulnerability to } \\
\text { natural disasters }\end{array}$ & $\begin{array}{l}\text { - Weak state incapable of } \\
\text { implementing or enforcing its } \\
\text { own policies } \\
\text { - Low price environment limits } \\
\text { availability of finance and } \\
\text { revenue } \\
\text { - Distrusting and lawless society }\end{array}$ \\
\hline
\end{tabular}




\section{Box 1: Demonstrating the Semi-Quantification Process for the 'Sound of Music' Scenario}

Following the development of the narrative storyline for the 'Sound of Music', a first interpretation of the narrative was performed by describing the state of each capital in the scenario, as demonstrated in the 'Sound of Music' row in Table 3. These interpretations were derived directly from panel discussions and the written language used for describing scenarios, as shown in Table 4. The five capitals framework provided a structure for consistently describing key drivers relevant to sustainable development, including measurable 'hard' drivers (such as economic growth and investment levels), as well as 'soft', difficult-to-measure drivers (such as the level of societal resilience and cooperation). Next, plausible consequences of the state of each capital in the 'Sound of Music' were formulated in terms of ordinal measures (e.g. high, medium, low) for elements of each capital asset. This step is a second layer of interpretation, ultimately translating the narrative scenario into explicit (ordinal) consequences for key drivers.

Thereafter, experts converted ordinal measures in to numerical measures for parameters required by the partial equilibrium and household-level food affordability models used in the South African case study. The process of moving from ordinal measures to numerical model inputs relied on the best guess of experts who matched the ordinal measures with corresponding ranges of parameter quantities as compared to baseline measures (however, to improve the transparency of the conversion process, this could have instead been done with the assistance of the scenario panel - see discussion in Section 5.2). For example, the plausible "low to high" range for economic growth (1.2\% to 4\%) was determined by pessimistic / optimistic scenarios of economic growth versus baseline projections developed by the International Monetary Fund (IMF) and the World Bank. Similarly, commodity prices were based on expectations of low/ high price scenarios relative to baseline projections for world commodity markets generated by the Food and Agricultural Policy Research Institute (FAPRI) at the University of Missouri (see BFAP [2015] and BFAP [2016] for a detailed description for how these baseline projections are built into the partial equilibrium model employed in this case study).

For some drivers, exploratory analysis informed the "low to high" range resulting in an informed guess used in semi-quantification. For example, the amount of cropland that is likely to be converted to mined land was determined through a GIS-based analysis, with the lower end of the range constituting $187500 \mathrm{ha}$ and the higher end of the range constituting 375 000ha (see BFAP 2015). Table A.1 and Table A.2 (extractions from the tables presented in the appendices) demonstrate respectively the semi-quantification of key drivers that were used in modelling the 'Sound of Music', as well as the reasoning behind the degree of semiquantification. 
Table A.1 (Extract): Macroeconomic assumptions by scenario, 9-year annual averages (2016-2024)

\begin{tabular}{|c|c|c|c|c|}
\hline & GDP growth rate & $\begin{array}{c}\text { Exchange rate } \\
\text { (ZAR vs USD) }\end{array}$ & $\begin{array}{c}\text { Oil Price } \\
\text { (USD/barrel) }\end{array}$ & $\begin{array}{c}\text { World Maize Price } \\
\text { (USD/ton) }\end{array}$ \\
\hline Baseline & $2.7 \%$ & $\mathrm{R} 16.04$ & $\$ 90$ & $\$ 198$ \\
\hline Sound of Music & $4.0 \%$ & $\mathrm{R} 12.88$ & $\$ 126$ & $\$ 252$ \\
\hline
\end{tabular}

Table A.2 (Extract): Reasoning behind assumptions used in the BFAP sector model

\begin{tabular}{|c|c|c|c|c|}
\hline \multirow{3}{*}{ Indicators } & \multirow{3}{*}{$\begin{array}{c}2015 \\
\text { (Baseline) }\end{array}$} & \multirow{3}{*}{$\begin{array}{c}2024 \\
\text { (Baseline) }\end{array}$} & \multicolumn{2}{|r|}{ Impact by 2024} \\
\hline & & & \multicolumn{2}{|r|}{ Sound of Music } \\
\hline & & & 2024 & Reason $^{a}$ \\
\hline Brent crude oil price & US\$ 67.20 & US\$ 90 & US\$ 126 & High commodity price environment \\
\hline US maize price & US\$ 177.20 & US\$ 198 & US\$ 252 & High commodity price environment \\
\hline $\begin{array}{l}\text { ZAR/USD exchange } \\
\text { rate }\end{array}$ & R 12.32 & R 16.04 & R 12.88 & Exceptional public financial management $(\mathrm{R} 2, \mathrm{C} 2)$ \\
\hline $\begin{array}{l}\text { South Africa's GDP } \\
\text { growth rate }\end{array}$ & $2.00 \%$ & $2.70 \%$ & $4.00 \%$ & Strong and steady economic growth $(\mathrm{R} 2, \mathrm{C} 2)$ \\
\hline $\begin{array}{c}\text { Cropland area } \\
\text { additionally utilized } \\
\text { by mining }\end{array}$ & 0 ha & 0 ha & 375000 ha & $\begin{array}{l}\text { Sustainable use of resources and sound land use } \\
\text { planning }(\mathrm{R} 2, \mathrm{C} 6)\end{array}$ \\
\hline $\begin{array}{l}\text { Average annual cash } \\
\text { crop yield growth }\end{array}$ & $0.05 \%$ & $0.05 \%$ & $1.90 \%$ & $\begin{array}{l}\text { Reduced pollution and enhanced ecosystem } \\
\text { services, integrity and resilience (R2,C6) }\end{array}$ \\
\hline
\end{tabular}

${ }^{a}$ Terms in parentheses refer to the respective row/column coordinates in Table 5

Even though quantitative modelling focussed on a limited set of 'hard' drivers, the five capitals framework enabled the incorporation 'soft drivers' both implicitly - providing the socioecological context in which agricultural and economic parameters emerged during narrative scenario discussions - and directly, enriching the interpretation of model outputs by providing the 'big picture' in which the model outputs were understood and communicated. 


\section{Discussion}

Several benefits emerged from using the five capitals framework in the South African case study. However, some pitfalls were also evident, especially in the form of missed opportunities for applying the framework in ways that could have enhanced the overall quality of the hybrid scenarios. Keeping in mind the problem-oriented and 'learning-by-doing' nature of the hybrid scenario exercise as it was applied in the South African case study, this section provides a preliminary evaluation of the strengths and weaknesses of the five capitals framework in addressing the conversion problem, while also highlighting several ways in which the application of the framework could be improved for hybrid scenario analysis.

\subsection{Advantages of using the five capitals framework}

The five capitals framework served as a practical tool for converting narrative scenario assumptions to inputs for numerical modelling. In particular, the framework provided structure for allocating ordinal measures to the drivers under each scenario. Thus, the conversion from narrative storylines to model parameters utilized a process of semi-quantification (i.e. based on ordinal measures), much like the conversion approach used in FCM (Kok 2009). In addition, juxtaposing the ordinal measures of scenario assumptions (as is done in Table 5) exposed any potential contradictions and inconsistencies between and within categories of capital assets (e.g. "does assumption $\mathrm{X}$ related to social capital match up with assumption $\mathrm{Y}$ and $\mathrm{Z}$ related to human and manufactured capital?"). In this way, the five capitals framework improved the consistency of narrative and quantitative scenarios. In addition, documenting the interpretation and semi-quantification process (as is demonstrated in Tables 3, 4, 5 and Table A.2 in Appendix A.2) improved the transparency ${ }^{7}$ of the conversion process.

Using the framework to interpret storylines also enabled the scenario team to think systematically and holistically about the types of assumptions embedded in the narrative scenarios. The identification and discussion of 'soft' drivers, although not directly included in the quantitative models, played a particularly interesting role in the formulation of macroeconomic assumptions for modelling, as well as enhancing the interpretation of the scenarios more generally. That is to say, without the systematic consideration of all five

\footnotetext{
${ }^{7}$ Although, the transparency of the conversion process would have been further improved if the conversion process had included panellists in a participatory approach, accompanied by comprehensive documentation of the panellists discussions regarding the underlying reasoning for the states of capital assets and the semi-quantification of key indicators (see discussion in section 5.2.).
} 
capitals, elements such as the 'extent of social cohesion and coordination within the economy' (an element of social capital in Table 3 and Table 5) or 'scope and capacity of research and development (R\&D)' (a consequence of human capital, as depicted in Table 5) would have received little or no attention since the emphasis would have been on quantifying macroeconomic assumptions needed for quantitative models.

Another potentially positive implication of the structure of the five capitals framework (although not directly shown in the South African study) is that, compared to more idiosyncratic approaches (e.g. Capitani 2016; Vervoort et al. 2014), it predefines theoreticallygrounded categories of indicators for semi-quantification such that comparisons can potentially be made across case studies and progress within particular case studies can be monitored and evaluated over time. The ability to compare indicators across case studies greatly enhances the salience of scenario methodologies for supporting sustainable development, especially given the importance of comparison, monitoring and evaluation for adaptive governance processes (Oteros-Rozas et al. 2015).

\subsection{Missed opportunities and lessons learned}

Despite the desirable aspects listed above, there were various problems with the way in which the framework was applied in the South African case study. In general, these pitfalls stemmed from the failure to include the scenario panel in the process of converting narrative scenario assumptions to inputs for numerical modelling (rather, these activities were implemented by the scenario team). This is unfortunate, since the simplicity of the five capitals framework suggests that it would be suitable as a participatory tool. This failure, in turn, emerged because the conversion problem only became apparent after the scenario development workshop. Additionally, owing to time and resource constraints that are typical of this type of project (i.e. a project which is not a purely academic undertaking), we were unable to reconvene the scenario panel to undertake the conversion process. Such an ad hoc and reflexive empirical application of the framework may be criticized by some as unconventional, 'unscientific', and lacking in academic rigour. Nonetheless, it is widely recognised in the academic literature that such methodological shortfalls are typical (indeed, even desirable) features of problemoriented scientific inquiry in the context of complex social-ecological systems (Cundill, Fabricius, and Marti 2005; Hinkel 2008; Kates et al. 2001) and post normal science more generally (Funtowicz and Ravetz 1993). 
Including the panellists in the conversion process would have enhanced the transparency of the conversion process, while stimulating further debate and exposing possible contradictions in the mental models of the panellists; mirroring the often-cited role that numerical model outputs play when reviewed by scenario panellists in a conventional SAS procedure (Alcamo 2008; Kemp-Benedict 2004). However, since the five capitals framework would ideally be applied earlier (i.e. at the end of phase 2 in Figure 1) in the overall scenario analysis than the revision process in SAS (at the end of phase 3 in Figure 1), there would be opportunity to identify and resolve inconsistent assumptions earlier, thus expediting the entire scenario analysis process.

More specifically, the study failed to transfer the responsibility of the semi-quantification from the scenario/modelling team to the scenario panellists themselves. Drawing on the procedure used in Vervoort et al. $(2014,387)$, the semi-quantification process can be performed by asking participants to provide what they think are the "directions and magnitudes of change for each indicator over multiple time steps, and [provide] the logic for these changes from the relevant scenario narrative. Capturing the logic behind each change helps interpret further analyses using the scenarios as well as the quantitative model outputs." Enabling the scenario panel to drive the semi-quantification process improves the transparency and objectivity of the conversion procedure. Comparable procedures are also suggested for CIBAS (Kosow 2011), FCM (Kok 2009), and in other applications of multi-stakeholder hybrid scenario analysis (e.g. Vervoort et al. 2014).

Another way in which the overall application of scenario analysis fell short in the South African case study was the failure to implement a process of iterative review and revision between the scenario panel and the modelling team (i.e. iteration between phases 2 and 3 in Figure 1). This problem emerged from time constraints, especially because of the limited time available for high-profile decision-makers and managers to participate in the scenario workshop. However, as we have already mentioned, using the five capitals framework as a participatory tool in the conversion process would partly replace the role of iterative revision in SAS for improving the consistency and transparency of the hybrid scenarios. Nonetheless, at least one or two rounds of revision could have been used to validate the resultant scenarios, thus potentially improving their scientific credibility. 
A more substantial limitation with the way that the five capitals framework was applied in the South African case study relates to the lack of explicit reflection on the dynamic links between the stocks and flows of different capital assets. This point is critical, since interactions and feedback mechanisms between capital stocks and flows can significantly alter system behaviour. We envisage several ways in which the application of the five capitals framework could be improved in this regard. For one, adopting the suggestions that we have already highlighted - i.e. using the five capitals as a participatory tool with emphasis on the clarification of underlying logic behind proposed directions and magnitudes of changes in specific indicators - would be a step in the right direction. Even better, pairing the five capitals framework with a form of FCM in the conversion process would provide a visual basis for identifying and cross-checking the states of the five capitals and their consequences for the magnitude and direction of change in key indicators. However, getting participants to construct a fuzzy cognitive map requires that the participants are at least familiar with flow diagrams and are capable of estimating strengths of relationships; this would not have been a problem in the South African study, given the composition of the panel, but could limit the usefulness of using FCM where the panel is composed of "laymen and freethinkers - groups that can be of great value to scenario development" (Kok 2009, 131). An additional trade-off of adding FCM to the conversion process is that it can be time-consuming and a focus on estimating the strengths of linkages can detract from the creative process of scenario development (Kok 2009). A reasonable suggestion might be to include a simple flow diagram to track the logic of panellists' discussions and motivations for net changes in indicators, and, if time allows, to add increasing levels of detail to this diagram in the form of estimated strengths of relationships. Ultimately, scenario teams need to find the middle-ground between relying on the implicit understanding of system dynamics as embedded in the mental models of experts and stakeholders and the explication of these dynamics for the benefit of verifiability and scientific rigour.

\subsection{Methodological trade-offs and recommendations for future research}

The approach which we have outlined in the preceding sections exhibits a number of similarities to other protocols for hybrid scenario analysis. In particular, the fundamentals of systematically identifying and making scenario assumptions explicit (via documentation in tables or diagrams and semi-quantification of driver variants), particularly in a participatory workshop with relevant stakeholders and experts, are common (e.g., Capitani et al. 2016; Kok 2009; Kosow 2011; Vervoort et al. 2014) . 
However, compared to these approaches, we hypothesize that there are three counts on which the five capitals framework has the potential to improve the expediency of a hybrid scenarios methodology:

- The simplicity of the framework means that fewer technical experts are needed to facilitate and validate the scenario analysis (especially compared to rigorous hybrid methodologies, such as, for instance, the expertise in cross-impact balances or systems dynamics required for CIBAS and FCM respectively).

- The framework can be readily understood and applied in a participatory setting, removing the constraint that panellists must consist of stakeholders both with relevant qualitative knowledge and the capability to understand and apply process such as crossimpact balances (cf. Kosow 2011 for the case of CIBAS), membership functions for fuzzy cognitive maps (cf. Kok 2009 for the case of FCM), and land use classing and spatial dynamics in land use and land cover changes scenarios (e.g. Capitani 2016).

- The ease with which the framework can be understood and applied in a participatory setting also potentially means that less time would be required to explain the mechanisms through which panellists are expected to interpret and semi-quantify scenario assumptions.

However, the expediency of using the five capitals framework comes at a cost; the simplicity of the framework necessarily implies a loss of mathematical rigour and scientific credibility that are associated with the thorough, time-rich protocols that comprise CIBAS and FCM for instance.

Nonetheless, the magnitude of the trade-off between rigor and expedience is not clear. It is quite possible, for instance, that using the five capitals framework as part of a SAS procedure may sacrifice some of the rigour of a comprehensive CIBAS protocol, but still capture the variants of 'big levers' to a sufficient degree to improve decision-making acumen in the context of pressing, complex sustainability issues. Consequently, a promising avenue for future research is to examine the implications of this methodological trade-off by comparing timerich, sophisticated protocols with more expedient approaches (such as the application of the five capitals framework in a SAS procedure) by examining the relative gain in scenario quality 
to the relative cost of scenario construction (in terms of time, required expertise, complexity, accessibility etc.). Kosow (2015) offers specific quality criteria for scenarios that may assist in such a comparison.

\section{Conclusion}

Hybrid scenario analysis methodologies are particularly well-suited to dealing with the normative, complex and uncertain dimensions of sustainable development. In this paper, we have put forward the five capitals framework as a wisdom-based and theoretically-grounded tool for overcoming the conversion problem in hybrid scenario analysis. In particular, we demonstrated that the application of the five capitals framework facilitates systematic and holistic thinking about key drivers - including those related to intangible, difficult-to-measure capital stocks - and their relative magnitudes under alternate possible futures.

Furthermore, we have suggested that the five capitals framework has the potential to improve the expedience of hybrid scenario analysis for resource-constrained government agencies, researchers and decision-makers. In light of the methodological trade-offs between rigour and expediency, future research needs to weigh up the benefits and costs of simple and feasible approaches versus comprehensive, time-rich protocols. Such an assessment is a step towards building decision-support tools which - while not perfect - are pragmatic and good 'enough' for improving the acumen of decision-makers and managers in responding timeously to the suite of urgent, messy, and multiscale challenges that shape current global environmental and social change. 


\section{References}

Alcamo, Joseph. 2008. Environmental Futures: The Practice of Environmental Scenario Analysis. Developments in Integrated Environmental Assessment Volume 2. Amsterdam, The Netherlands: Elsevier. doi:10.1016/S1574-101X(08)00406-7.

Arrow, Kenneth, Partha Dasgupta, Lawrence H. Goulder, Gretchen Daily, Paul Ehrlich, Geoffrey Heal, Simon A. Levin, et al. 2004. “Are We Consuming Too Much?” Journal of Economic Perspectives 18 (3): 147-172.

Arrow, Kenneth, Partha Dasgupta, Lawrence H. Goulder, Kevin J. Mumford, and Kirsten Oleson. 2012a. "Sustainability and the Measurement of Wealth." Environment and Development Economics 17 (3): 317-353. doi:10.1017/S1355770X12000186.

Arrow, Kenneth, Partha Dasgupta, Lawrence H. Goulder, Kevin J. Mumford, and Kirsten Oleson. 2012b. "Sustainability and the Measurement of Wealth: Further Reflections." Environment and Development Economics 18 (4): 504-516. doi:10.1017/S1355770X12000186.

Bai, Xuemei, Sander van der Leeuw, Karen O’Brien, Frans Berkhout, Frank Biermann, Eduardo S. Brondizio, Christophe Cudennec, et al. 2015. "Plausible and Desirable Futures in the Anthropocene: A New Research Agenda." Global Environmental Change 39 (2016): 351-362. doi:10.1016/j.gloenvcha.2015.09.017.

Berkhout, Frans, Julia Hertin, and Andrew Jordan. 2002. "Socio-Economic Futures in Climate Change Impact Assessment: Using Scenarios as 'learning Machines." Global Environmental Change 12 (2002): 83-95. doi:10.1016/S0959-3780(02)00006-7.

Biggs, Duan, Reinette Biggs, Vasilis Dakos, Robert J. Scholes, and Michael Schoon. 2011. "Are We Entering an Era of Concatenated Global Crises?" Ecology and Society 16 (2): 27. http://www.ecologyandsociety.org/vol16/iss2/ art27/.

Biggs, Reinette, Clint Rhode, Sally Archibald, Lucky Makhosini Kunene, Shingirirai S. Mutanga, Nghamula Nkuna, Peter Omondi Ocholla, and Lehlohonolo Joe Phadima. 2015. "Strategies for Managing Complex Social-Ecological Systems in the Face of Uncertainty: Examples from South Africa and beyond." Ecology and Society 20 (1): 52. doi:10.5751/ES-07380-200152.

Blore, Megan, Georgina Cundill, and Mazwi Mkhulisi. 2013. "Towards Measuring the Transaction Costs of Co-Management in Mkambati Nature Reserve, Eastern Cape, South Africa." Journal of Environmental Management 129 (2013): 444-455. doi:10.1016/j.jenvman.2013.08.002.

Booth, Eric G., Jiangxiao Qiu, Stephen R. Carpenter, Jason Schatz, Xi Chen, Christopher J. Kucharik, Steven P. Loheide II, et al. 2016. "From Qualitative to Quantitative Environmental Scenarios: Translating Storylines into Biophysical Modeling Inputs at the Watershed Scale." Environmental Modelling \& Software 85 (2016): 80-97. doi: 10.1016/j.envsoft.2016.08.008.

Bradfield, Ron, George Wright, George Burt, George Cairns, and Kees Van Der Heijden. 2005. "The Origins and Evolution of Scenario Techniques in Long Range Business Planning." 
Futures 37 (8): 795-812. doi:10.1016/j.futures.2005.01.003.

Bureau for Food and Agricultural Policy (BFAP). 2012. Evaluating the Impact of Coal Mining on Agriculture in the Delmas, Ogies and Leandra Districts: A Focus on Maize Production. Pretoria. http://www.bfap.co.za/documents/research reports/The impact of coal mining on agriculture - a Pilot study focus, based on maize production (2012).pdf.

Bureau for Food and Agricultural Policy (BFAP). 2015. The Balance of Natural Resources: Understanding the Long Term Impact of Mining on Food Security in South Africa. Pretoria. http://www.bfap.co.za/documents/research reports/Agriculture and Mining_The Balance of Natural Resources.pdf.

Bureau for Food and Agricultural Policy (BFAP). 2016. BFAP Baseline: Agricultural Outlook 2016-2025. Pretoria. http://www.bfap.co.za/index.php/baselines.

Capitani, Claudia, Kusaga Mukama, Boniface Mbilinyi, Isaac O. Malugu, Pantaleo K.T. Munishi, Neil D. Burgess, Philip J. Platts, et al. 2016. "From Local Scenarios to National Maps: A Participatory Framework for Evisioning the Future of Tanzania." Ecology and Society 21(3):4. doi:10.5751/ES-08565-210304.

Chambers, Robert, Gordon R. Conway. 1992. "Sustainable Rural Livelihoods: Practical Concepts of the 21st Century". IDS Discussion Paper, No. 296. Brighton: UK Institute for Development Studies.

Clarke, Marlea, and Carolyn Bassett. 2016. "The Struggle for Transformation in South Africa: Unrealised Dreams, Persistent Hopes.” Journal of Contemporary African Studies 34 (2). Taylor \& Francis: 183-189. doi:10.1080/02589001.2016.1202501.

Cundill, Georgina, Christo Fabricius, and Neus Marti. 2005. "Foghorns to the Future: Using Knowledge and Transdisciplinarity to Navigate Complex Systems." Ecology and Society 10 (2): 8 .

Dasgupta, Partha. 2009. "The Welfare Economic Theory of Green National Accounts." Environmental and Resource Economics 42 (1): 3-38. doi:10.1007/s10640-008-9223-y.

Dasgupta, Partha. 2015. "Disregarded Capitals: What National Accounting Ignores." Accounting and Business Research 45 (4): 447-464. doi:10.1080/00014788.2015.1033851.

Dasgupta, Partha, and Karl-Göran Mäler. 2000. "Net National Product, Wealth, and Social Well-Being." Environment and Development Economics 5 (2000): 69-93. doi:10.1017/S1355770X06003020.

Ellis, Frank. 2000. "Rural Livelihoods and Diversity in Developing Countries". Natural Resource Perspectives, No. 40. London: Overseas Development Institute.

Esler, K.J., L. Downsborough, D.J. Roux, J. Blignaut, S. Milton, D. le Maitre, and M.P. de Wit. 2016. "Interdisciplinary and Multi-Institutional Higher Learning: Reflecting on a South African Case Study Investigating Complex and Dynamic Environmental Challenges." Current Opinion in Environmental Sustainability 19 (1). Elsevier B.V.: 76-86. doi:10.1016/j.cosust.2015.12.002. 
Fine, Ben. 2002. "They F**k You Up Those Social Capitalists." Antipode 34 (4): 796-799. doi:10.1111/1467-8330.00271.

Folke, Carl, Steve Carpenter, Thomas Elmqvist, Lance H. Gunderson, C. S. Holling, and Brian Walker. 2002. "Resilience and Sustainable Development: Building Adaptive Capacity in a World of Transformations." Ambio 31 (5): 437-440.

Funtowicz, Silvio O., and Jerome R. Ravetz. 1993. "Science for the Post-Normal Age." Futures 25 (7): 739-755. doi:10.1016/0016-3287(93)90022-L.

Grootaert, Christiaan, and Thierry van Bastelaer. 2001. "Understanding and Measuring Social Capital: A Synthesis of Findings and Recommendations from the Social Capital Initiative." Social Capital Initiative Working Paper Series, No. 24. Washington, D.C.: The World Bank.

Hinkel, Jochen. 2008. "Transdisciplinary Knowledge Integration: Cases from Integrated Assessment and Vulnerability Assessment." PhD Thesis, Wageningen University, The Netherlands. http://basarab.nicolescu.perso.sfr.fr/ciret/biblio/biblio_pdf/Hinkel.pdf.

Kates, Robert W., William C. Clark, Robert Corell, J. Michael Hall, Carlo C. Jaeger, Ian Lowe, James J. Mccarthy, et al. 2001. “Sustainbility Science.” Science 292 (5517): 641-642.

Kemp-Benedict, Eric. 2004. "From Narrative to Number: A Role for Quantitative Models in Scenario Analysis." In iEMSs 2004 International Congress: "Complexity and Integrated Resources Management," edited by C. Pahl-Wostl, S. Schmidt, and T. Jakeman. Osnabrueck, Germany: International Environmental Modelling and Software Societey.

Kemp-Benedict, Eric. 2013. "Going from Narrative to Number: Indicator-Driven Scenario Quantification." In Recent Developments in Foresight Methodologies, edited by Maria Giaoutzi and Bartolomeo Sapio, 123-131. Boston, MA: Springer US. doi:10.1007/978-14614-5215-7_8.

Kok, Kasper. 2009. "The Potential of Fuzzy Cognitive Maps for Semi-Quantitative Scenario Development, with an Example from Brazil." Global Environmental Change 19 (2009): 122-133. doi:10.1016/j.gloenvcha.2008.08.003.

Kok, Kasper, and Hedwig van Delden. 2009. "Combining Two Approaches of Integrated Scenario Development to Combat Desertification in the Guadalentín Watershed, Spain." Environment and Planning B: Planning and Design 36 (1): 49-66. doi:10.1068/b32137.

Kosow, Hannah. 2011. Consistent Context Scenarios: A New Approach to Story and Simulation. The 4th International Seville Conference on Future-Oriented Technology Analysis (FTA). FTA and Grand Societal Challenges - Shaping and Driving Structural and Systemic Transformations SEVILLE, 12-13 MAY 2011. Seville.

Kosow, Hannah. 2015. "New Outlooks in Traceability and Consistency of Integrated Scenarios." European Journal of Futures Research 3 (1): 16. doi:10.1007/s40309-0150077-6.

Louw, Marlene. 2017. “An Econometric Analysis of Food Inflation in South Africa.” D(Com) Thesis, University of Pretoria, Pretoria. 
Millenium Ecosystem Assessment. 2005. Ecosystems and Human Well-Being. Washington, D.C.: Island Press. doi:10.1196/annals.1439.003.

Ostrom, Elinor, and T K Ahn. 2009. "The Meaning of Social Capital and Its Link to Collective Action." In Handbook of Social Capital: The Troika of Sociology, Political Science and Economics, edited by G.T. Svendsen and G.L.H. Svendsen, 17-35. Elgar Original Reference Series. Northampton, USA: Edward Elgar.

Oteros-Rozas, Elisa, Berta Martín-López, Tim M. Daw, Erin L. Bohensky, James R A Butler, Rosemary Hill, Julia Martin-Ortega, et al. 2015. "Participatory Scenario Planning in Place-Based Social-Ecological Research: Insights and Experiences from 23 Case Studies.” Ecology and Society 20 (4): 32. doi:10.5751/ES-07985-200432.

Peterson, Garry D., Graeme S. Cumming, and Stephen R. Carpenter. 2003. "Scenario Planning: A Tool for Conservation in an Uncertain World." Conservation Biology 17 (2): 358-366.

Putnam, Robert D. 1993. Making Democracy Work: Civic Traditions in Modern Italy. Princeton, New Jersey: Princeton University Press.

Rees, William E. 1995. "Cumulative Environmental Assessment and Global Change." Environmental Impact Assessment Review 15 (95): 295-309.

Riahi, Keywan, Detlef P. van Vuuren, Elmar Kriegler, Jae Edmonds, Brian C. O’Neill, Shinichiro Fujimori, Nico Bauer, et al. 2017. "The Shared Socioeconomic Pathways and Their Energy, Land Use, and Greenhouse Gas Emissions Implications: An Overview." Global Environmental Change 42: 153-168. doi:10.1016/j.gloenvcha.2016.05.009.

Robinson, John. 2004. "Squaring the Circle? Some Thoughts on the Idea of Sustainable Development." Ecological Economics 48 (4): 369-384. doi:10.1016/j.ecolecon.2003.10.017.

Rockström, Johan, W.L. Steffen, Kevin Noone, Persson Asa, and F.S. Stuart Chapin III. 2009. "Planetary Boundaries: Exploring the Safe Operating Space for Humanity." Ecology and Society 14 (2): 32. doi:10.1007/s13398-014-0173-7.2.

Schultz, Theodore W. 1961. "Investment in Human Capital." The American Economic Review $51(1): 1-17$.

Serageldin, Ismail. 1996. "Sustainability as Opportunity and the Problem of Social Capital." The Brown Journal of World Affairs 3 (2): 187-203.

Solow, Robert M. 1999. "Notes on Social Capital and Economic Performance." In Social Capital: A Multifaceted Perspective, edited by Partha Dasgupta and Ismail Serageldin, 610. Washington, D.C.: The World Bank.

Swart, R.J., P Raskin, and J. Robinson. 2004. "The Problem of the Future: Sustainability Science and Scenario Analysis." Global Environmental Change 14 (2): 137-146. doi:10.1016/j.gloenvcha.2003.10.002.

United Nations. 2016. "The Sustainable Development Agenda." http://www.un.org/sustainabledevelopment/development-agenda/. 
Uphoff, Norman. 2000. "Understanding Social Capital: Learning from the Analysis and Experience of Participation." In Social Capital: A Multifaceted Perspective, edited by Partha Dasgupta and Ismail Serageldin, 215-249. Washington, D.C.: World Bank.

Van Notten, Philip W.F., Jan Rotmans, Marjolein B.A. van Asselt, and Dale S. Rothman. 2003. "An Updated Scenario Typology." Futures 35 (5): 423-443. doi:10.1016/S00163287(02)00090-3.

Vervoort, Joost M., Philip K. Thornton, Patti Kristjanson, Wiebke Förch, Polly J. Ericksen, Kasper Kok, John S.I. Ingram, et al. 2014. "Challenges to Scenario-Guided Adaptive Action on Food Security under Climate Change." Global Environmental Change 28 (2014): 383-394. doi:10.1016/j.gloenvcha.2014.03.001.

Westhoff, Patrick. 2010. The Economics of Food: How Feeding and Fueling The Planet Affects Food Prices. New Jersey: Pearson Education, FT Press.

World Commission on Environment and Development (WCED). 1987. Our Common Future. Oxford: Oxford University Press. 